\title{
The University of Toronto through Historians' Eyes
}

\author{
Paul Axelrod
}

There is something old and something new in the historiography of Canadian higher education. If you stroll through the stacks of any university library and examine what was published on the history of universities before the 1970s, this is what you would be likely to find: volumes of institutional biographies written by ex-presidents or retiring professors in which the themes of struggle, endurance, survival, and accomplishment dominate. The specific issues in such accounts include the activities of successive dedicated presidents, fund-raising efforts, descriptions of new buildings and new academic programs, and the careful recording of football championships.

The struggle and survival theme matters, and, in all likelihood, is a central part of the story of every Canadian university. It is also fairly safe to say that one can take for granted the devotion to their institutions of university presidents, chancellors, and other senior administrators, except perhaps in the case of the chairman of the board at the University of Manitoba who, in 1932, was found to have embezzled nearly 1 million dollars over the previous three decades. ${ }^{1}$ However important, the stories of institutional endurance and dedicated individuals are not necessarily the most interesting themes. More stimulating, and more significant historiographically, at least to me, is the study of the university's intellectual, cultural, and social worlds - and how these have cast light on the life of the community in which the university is situated.

New research in the last quarter-century has grappled creatively with the evolving academic experience. Reflecting the impact primarily of intellectual and social history, the historiography of higher education now explores the ways in which ideas are cultivated and transmitted within and beyond universities.

1 J.M. Bumsted, The University of Manitoba: An Illustrated History (Winnipeg: The University of Manitoba Press, 2001), 75-77.

(c) Historical Studies in Education/Revue d'histoire de l'éducation 14, 2 (2002): 299-308 
How secular values came to dominate university thinking over the past century is one important theme in the literature. Others include the social origins of students, the culture of professionalism, the experience of women, the hierarchy of student life, and the struggles for academic freedom.

Not since W. Stewart Wallace's A History of the University of Toronto, 1827-1927 (Toronto, 1927), has anyone successfully written a history of $\mathrm{U}$ of $\mathrm{T}$-not, that is, until Martin Friedland. But the University of Toronto has not exactly been ignored by historians, and in the brief time I have, I want to talk first, and rather selectively, about some of the newer literature on the $U$ of $T$, and then end with a preliminary assessment of where Professor Friedland's book can be situated within the historiography.

In the world of excessive academic specialization, historians rarely attempt to write surveys, particularly those that are comprehensive and drawn from primary research. In the field of higher education, this is especially noticeable: intellectual and social historians too infrequently interact, and their scholarship generally explores social or intellectual life, not both. One major exception to this trend is Brian McKillop's Matters of Mind: The University in Ontario, 1791-1951 (Toronto, 1994), a book that grows increasingly impressive with the passage of time. A history of universities in Ontario from 1791 to 1950, it naturally includes a wealth of material on the University of Toronto. The book traces the political origins of the university in the nineteenth century — and it was very much a political project-and proceeds to weave a tale infused with both intellectual and social history. In this account, the University of Toronto was moulded by both the pragmatic pressures of an emerging industrial capitalist society, and the cultural values of a maturing British colony. At times these influences reinforced each other; on other occasions they were the source of academic and political tension. By 1950, U of T reflected and reproduced the conservative beliefs and the economic preoccupations of the community that surrounded it. It was governed by a business elite, it trained middle-class professionals, it encouraged patriotism, it tolerated dissent (within limits), and it was sceptical of, though not uniformly opposed to, academic innovation. It was no longer ruled by religious authority, but it still 
privileged, at both the faculty and student levels, white Christian males. ${ }^{2}$

The book draws on McKillop's own earlier research on Canadian intellectual and curricular life, and on that of other historians. One can study university curricula as Robin Harris did, by writing the equivalent of an encyclopaedic university calendar, ${ }^{3}$ or, more compellingly, by attempting to get inside the minds of university teachers. The latter is McKillop's approach, and that of other intellectual historians whose studies focus on, or substantially include, the work of some influential $U$ of $T$ professors. Heather Murray, for example, recreates the controversial appointment of W.J. Alexander in 1889 to the first Chair in English, thereby stimulating more specialized literary studies in Canada; Alexander promoted the concept that "art and literature constituted a unique approach to the understanding and enjoyment of life."4 In an earlier article, Patricia Jasen traced the emergence in the nineteenth century of English as the core liberal arts subject at $U$ of $T$ and elsewhere. Jasen's unpublished thesis follows the modernization of the English- Canadian liberal arts curriculum into the early twentieth century. ${ }^{5}$

Historians, not surprisingly, have paid special attention to the study of history at the University of Toronto. Carl Berger's The Writing of Canadian History (1976) was a model of lucidity in tracing the major interpretive themes in English-Canadian historiography, in which U of $\mathrm{T}$ historians Innis, Creighton, and Underhill had a starring role. (One should place no particular significance on the fact that two of U of T's most famous historians were named Careless and Wrong). Robert Bothwell's history of the history department briefly covers enormous territory and time,

2 For a fuller review of this book see Paul Axelrod, "Keepers of the Mind,” The Literary Review of Canada, June 1994, 18-19.

3 Robin S. Harris, A History of Higher Education in Canada, 1663-1960 (Toronto: University of Toronto Press, 1976).

4 Heather Murray, Working in English: History, Institution, Resources (Toronto: University of Toronto Press 1996), citing Malcolm Wallace, 19.

5 Patricia Jasen, “Arnoldian Humanism, English Studies, and the Canadian University,” Queen's Quarterly 95, 3 (Autumn 1988); Patricia Jasen, “The English Canadian Liberal Arts Curriculum: An Intellectual History, 1800-1950” (Ph.D. thesis, University of Manitoba, 1987). 
and undoubtedly raised the hackles of some of his colleagues. ${ }^{6}$ It traces the transition of a unified undergraduate department with a singular curriculum designed to build character and citizenship in a neo-Imperial, Oxfordian caste, to a more fragmented professional department stressing research, specialized study, graduate work, and academic choice. In my view, this is a perceptive rendering, and is applicable not only to other history departments but to other academic disciplines throughout Canada. What happened to the history department at Toronto happened elsewhere.

A fascinating, if often arcane, historiographical debate has centred on the degree and pace of "secularization" in Canadian universities. (Some question the use of the concept of secularization itself.) One requires, in Professor McKillop's term, a "disciplined intelligence" to follow the tortuous theological debates among the historians and their subjects, a number of whom were University of Toronto professors. Michael Gauvreau, David Marshall, Ramsay Cook, Margaret Van Die, Neil Semple, Brian Fraser, and Bill Westfall, ${ }^{7}$ among others, have written substantively on this theme, inspired in part by McKillop's pioneering work on the intellectual and religious culture of Victorian Canada.

A key point of contention appears to be whether Christian perspectives were subsumed by or themselves infused the modernization of Canadian society through the industrial era. For example, Michael Gauvreau believes that the "clergymenprofessors" and the intellectuals they influenced at Toronto and English Canada, as a whole, were not mere idealists, engaged in the

6 Robert Bothwell, Laying the Foundation: A Century of History at University of Toronto (Toronto: University of Toronto Department of History, 1991).

7 Michael Gauvreau, The Evangelical Century: College and Creed in English Canada from the Great Revival to the Great Depression (Montreal: McGill-Queen's University Press, 1991); David Marshall, Secularizing the Faith: Canadian Protestant Clergy and the Crisis of Belief, 1850-1940 (Toronto: University of Toronto Press, 1992); Ramsay Cook, The Regenerators: Social Criticism in Late Victorian Canada (Toronto: University of Toronto Press, 1985); Marguerite Van Die, An Evangelical Mind: Nathanael Burwash and the Methodist Tradition in Canada, 1839-1918 (Montreal and Kingston: McGillQueen's University Press, 1989); Neil Semple, The Lord's Dominion: The History of Canadian Methodism (Montreal and Kingston: McGill-Queen's University Press, 1996); Brian Fraser, Church, College, and Clergy: A History of Theological Education at Knox College, Toronto, 1844-1994 (Montreal and Kingston: McGill-Queen's University Press, 1994); William Westfall, Two Worlds: The Protestant Culture of Nineteenth-Century Ontario (Montreal and Kingston: McGill-Queen’s University Press, 1989). 
process of adapting Christianity to secular pressures, but were important and, at times, original thinkers who successfully forged an "intellectually respectable theological alternative to the evolutionary human sciences.” From this perspective, Robert Falconer, president from 1907 to 1932, was far more than the "garden variety idealist” that his biographer James Greenlee claims him to be. To Gauvreau, he was an exponent of the "evangelical creed," which distanced his thinking from the "main tenets of theological liberalism." 8

Given my own academic specialization, I couldn’t possibly pretend to declare a winner in this great theological debate, but it does underline for me the need for intellectual and social history to be examined in combination. What matters, in other words, is not only what Robert Falconer thought but what he did. (The same would be true for other presidents and professors). My reading of the historians' assessments is that Falconer attempted, with mixed success, to leave a moral imprint, derived from his Christian beliefs, on the life of $U$ of $T$, while simultaneously embracing the demands of industry and urban life. It is surely significant, though in ways that remain to be fully explained, that Robert Prichard considered Falconer to be the greatest influence on his own presidency. ${ }^{9}$

By virtue of their brilliance, their influence, and/or their public notoriety, three professors at $\mathrm{U}$ of $\mathrm{T}$ have been the subjects of scholarly and popular writing, and one could be forgiven for concluding that for the longest time, Harold Innis, Northrop Frye, and Marshall McLuhan were the only people teaching at the University. Beyond the fascinating details of their lives and work is this interesting question, at least to me: how is that two of the three (Innis and McLuhan) became such renowned public intellectuals when they wrote such impenetrable prose? Indeed the study of the University of Toronto and the public intellectual in Canada is a great topic for a Ph.D. thesis. (I expect someone's going to tell me it's already been done and that I haven't read it.)

If this particular question has yet to be addressed, we certainly know a good deal more about the history of U of T's academic life

8 Gauvreau, The Evangelical Century, 201, 207; James Greenlee, Sir Robert Falconer: A Biography (Toronto: University of Toronto Press, 1988).

9 Said in a 1999 CBC Radio interview. 
by virtue of a number of other impressive studies published in recent years. Bob Gidney and Wyn Millar explored in penetrating detail the socially constructed concept of professionalism in the nineteenth century and its evolving relationship with higher education, including, of course, the University of Toronto. ${ }^{10}$ Michael Bliss's biography of Banting and his history of the discovery of insulin ${ }^{11}$ demystified the mysterious world of medical research at $\mathrm{U}$ of $\mathrm{T}$, and in a boldly revisionist judgement, Bliss called into question the reputation and legacy of Banting himself, a conclusion echoed by Martin Friedland.

There is certainly space for additional histories of the professions at $\mathrm{U}$ of $\mathrm{T}$, which can draw inspiration and information from Jan Kyer and Jerome Bickenbach's study of law, from Richard White's recent history of the engineering faculty, and from Ruby Heap's work on physiotherapy and dietetics. ${ }^{12}$

Women's studies has had an enormous influence on the writing of Canadian social history, something well illustrated in the literature on the University of Toronto. For many years, Alison Prentice has been probing the careers of the once-invisible female Toronto academics including Mossie May Kirkwood and a number of women physicists whose scholarly contributions and careers were simultaneously significant and marginalized. ${ }^{13}$ Professor Prentice's research was so dogged that one of the physicists she

10 R.D. Gidney and W.P.J. Millar, Professional Gentlemen: The Professions in Nineteenth-Century Ontario (Toronto: University of Toronto Press, 1994). See also R.D. Gidney and W.P.J. Millar, "The Reorientation of Medical Education in Late-NineteenthCentury Ontario; The Proprietary Medical Schools and the Founding of the Faculty of Medicine at the University of Toronto," The Journal of the History of Medicine and Allied Sciences 49 (1994): 52-78.

11 Banting: A Biography, 2d paperback ed. (Toronto: University of Toronto Press, 1992), and The Discovery of Insulin (Toronto: McClelland and Stewart, 1982).

11 C. Ian Kyer and Jerome E. Bickenbach, The Fiercest Debate: Cecil Wright, the Benchers, and Legal Education in Ontario (Toronto: University of Toronto Press, 1987); Richard J. White, The Skule Story: The University of Toronto Faculty of Applied Science and Engineering, 1873-2000 (Toronto: University of Toronto Press, 2000); Ruby Heap, “Training Women for a New 'Woman's Profession': Physiotherapy Education at the University of Toronto, 1917-1980,” History of Education Quarterly 35, 2 (1995): 135-58. 12 Alison Prentice, "Scholarly Passion: Two Persons Who Caught It," Historical Studies in Education 1, 1 (Spring 1989): 7-28; Alison Prentice, "Three Women in Physics," in Challenging Professions: Historical and Contemporary Perspectives on Women's Professional Work, ed. Elizabeth Smyth et al. (Toronto: University of Toronto Press, 1999), 119-40. 
identified as a woman, Vivian Pound, turns out to have been a man, a startling fact uncovered by Charles Levi in his research on the history of the University of Toronto project. ${ }^{14}$

Sara Burke's Seeking the Highest Good: Social Service and Gender at the University of Toronto, 1880-1937 (Toronto: 1996) explores the intellectual origins and gender-based power relations that shaped the development of social work at the University of Toronto in the early twentieth century. This is a complex story which illustrates the ways in which women forged a distinctive but subordinate position in the $\mathrm{U}$ of $\mathrm{T}$ academic hierarchy, something that was characteristic of women's place in the health and so-called "caring” professions. ${ }^{15}$

Studies of student life also include women's experience at the University of Toronto and other institutions. The literature explores what, in effect, is the hidden curriculum of classroom and extra-curricular life. What values did students bring to their studies and interactions, how did they deal with authority, and what character-building and citizenship traits did the university attempt to cultivate in its students? Keith Walden, Sara Burke, Janet Kiefer, Ruth Pierson, Catherine Gidney, Alyson King, and Charles Levi have explored issues such as the meaning of initiation rituals, the significance of the1895 student strike, the campus activism of women in World War II, the emergence of the Student Christian Movement, the moral architecture of university residences, and the post-university destinies of Lit society leaders from University

13 Alison Prentice, "Vivian Pound Was A Man? The Unfolding of a Research Project," Historical Studies in Education 13, 2 (2001): 99-112.

14 Ruby Heap, "From the Science of Housekeeping to the Science of Nutrition: Pioneers in Canadian Nutrition and Dietetics at the University of Toronto's Faculty of Household Science, 1900-1950,” in Challenging Professions, ed. Smyth et al., 141-70; W.P.J.Millar and R.D. Gidney, “'Medettes': Thriving or Just Surviving? Women Students in the Faculty of Medicine, University of Toronto, 1910-1951,” ibid., 215-33; and Carol Baines, "Professor Elizabeth Govan: An Outsider in Her Own Community," ibid., 44-64. See also Hans Pols, “The World as Laboratory: Strategies of Field Research Developed by Mental Hygiene Psychologists in Toronto, 1920-1940,” in The Development of the Social Sciences in the United States and Canada: The Role of Philanthropy, ed. Theresa Richardson and Donald Fisher (Stamford, Connecticut: Albex Publishing Corporation, 1999), 115-42. 
College. ${ }^{16}$ As they continue to research the lives of students through the prism of gender-analysis, historians, in my view, should no longer isolate the women from the men, but should examine their experiences comparatively. This will be especially important for work on the post-1960s period when the number of undergraduate females came to equal, and then surpass, that of males. It will be important, too, to take the ethnic, racial, and cultural diversity of the student population into account in new research.

Before turning briefly to Martin Friedland's book, let me say something about the genre of autobiography which, in recent years, has shed some revealing light on the history of the University of Toronto. Four recent memoirs by Jill Conway, Kenneth McNaught, H. Gordon Skilling, and Ernest Sirluck are absorbing, informative accounts of teaching and administrative practices by individuals who have written colourfully, frankly, and at times, combatively, about campus life. ${ }^{17}$ This was also true of Claude Bissell's 1974 memoir, Halfway Up Parnassus (Toronto, 1974). Autobiographies are, by definition, self-serving, so these writers are unlikely to have the last word on the subjects they discuss (including the subject of themselves). But they have insightful, and often surprising, things to say on such topics as the treatment of women faculty, anti-semitism, and the student movement. I was

15 Keith Walden, "Hazes, Hustles, Scraps, and Students: Initiations at the University of Toronto, 1880-1925," in Youth, University, and Canadian Society: Essays in the Social History of Higher Education, ed. Paul Axelrod and John G. Reid (Montreal and Kingston: McGill-Queen's University Press, 1989), 94-121; Janet Kiefer and Ruth Roach Pierson, “The War Effort and Women Students at the University of Toronto, 1939-45," ibid., 16183; Alyson King, "Centres of Home-Like Influence: Residences for Women in the University of Toronto,” Material History Review 49 (Spring 1999): 39-59; Sara Burke, “'Being Unlike Man:' Challenges to Co-education at the University of Toronto,18841909,” Ontario History 93, 1 (Spring 2001): 11-31; Catherine Gidney, "Poisoning the Student Mind? The Student Christian Movement at the University of Toronto, 19201960," Journal of the Canadian Historical Association 8 (1997): 147-63; Charles Levi, "Where the Famous People Were: The Origins, Activities and Future Careers of Student Leaders at University College, Toronto, 1854-1973” (Ph.D. thesis, York University, 1998).

16 Jill Ker Conway, True North (New York: Alfred A. Knopf, 1994); Kenneth McNaught, Conscience and History (Toronto: University of Toronto Press, 1999); H. Gordon Skilling, The Education of a Canadian: My Life as a Scholar and Activist (Montreal and Kingston: McGill-Queen’s University Press, 2000); Ernest Sirluck, First Generation: An Autobiography (Toronto: University of Toronto Press, 1996). 
especially intrigued by the evocative descriptions of teaching styles of well known, and lesser known, professors. Did you know, for example, that Donald Creighton gave Kenneth McNaught an "A" for his "socialist critique" of the Rowell-Sirois Report on federalprovincial relations? There are stories, too, of students who later became professors and politicians. Here, again, is a wonderful subject for further research - the history of university teaching, and biographical anecdotes, are a good place to begin.

Many of these, and much else, of course, can be found in Martin Friedland's impressive new history of the University of Toronto. Those of us who toil on our own projects for years, and too often have too little to show for it, can only be amazed at the pace of research and writing set and fulfilled by Professor Friedland. In barely four years, the project was conceived and completed. It is elegantly written, beautifully illustrated, and majestically produced, and already has been well received. And historians in the largely unrecognized field of university history can only marvel at the marketing success of a book with the $\mathrm{U}$ of $\mathrm{T}$ publicity machine behind it. I've even seen it for sale in airports!

Historiographically, Professor Friedland's book has one foot in the old world and one foot in the new. This volume is unmistakably a celebration of the University in which successive presidents, new buildings and emerging faculties occupy centre stage. It is difficult to identify a core thesis or a grand narrative that weaves the story together; the book consists of events and episodes, of characters and controversies, that gave life to the institution. One comes away from the study, especially in the wake of the author's final evocative tour through the nooks and crannies of $U$ of $T$, with a strong sense of his great affection for the institution. At the same time, throughout his journey, Friedland peers under some aging rocks, and effectively explores a number of important debates and conflicts.

The author draws extensively, and with full acknowledgement, from the work of social (though far less from intellectual) historians. In that no one, until Friedland, has produced a narrative of the contemporary history of the university, the last section of the book, that which covers the period from the 1950s to 2000, is, in my view, its most original contribution to the historiography. Friedland has provided a succinct and readable account of the recent era. Furthermore, he has written about ex-students, professors, and administrators who are very much alive and, if they 
are so inclined, able to take issue with the book's account of their academic and administrative adventures. As well as being bold by writing up to the present, the author is adept. As a former law dean, he knows, among many other things, how to avoid being sued.

My final observation is about the university itself. This book has helped me form a historical judgement about the University of Toronto that, until now, I could never quite articulate. Let me state it this way: for most of its history $\mathrm{U}$ of $\mathrm{T}$ was the provincial and $a$ provincial university. Well situated geographically and politically, it has enjoyed a favoured status with various provincial governments. Yet, this study convinced me, whether it intended to or not, that until the expansion of its graduate programs in the 1960s, and the building of the Robarts Library, U of T was not especially academically distinctive. Honours students certainly received a first-rate education, but pass students, who constituted the majority of undergraduates, did not, as virtually everyone acknowledged. The research culture, in arts and science, was episodically, but not continuously, noteworthy. Reflecting the state of higher education in the rest of English Canada, $\mathrm{U}$ of $\mathrm{T}$, for most of its history, was inward-looking, and only rarely academically innovative. Thus, while its reputation in Canada has, arguably, always been large, its most distinctive academic accomplishments arise more from the very recent era than from the distant past. I am grateful to Professor Friedland for guiding me to this insight, even if, as is probably the case, he disagrees with it. Historians, after all, often view the past through different eyes. 